\title{
Study on Imported Case Dimorphic Fungi Isolated from Clinical Specimen in Korea
}

\author{
Jang Ho Lee ${ }^{1}$, Sungryul Yu ${ }^{1}$, Bon-Kyung Koo ${ }^{2}$, Cheol Moon ${ }^{1}$ \\ ${ }^{1}$ Department of Clinical Laboratory Science, Semyung University, Jecheon, Korea \\ ${ }^{2}$ Department of Laboratory Medicine, Samsung Medical Center, Seoul, Korea
}

\section{한국의 임상검체로부터 분리된 해외유입 두 형태 진균에 대한 연구}

\author{
이장호 ${ }^{1}$, 유성률 $^{1}$, 구본경 $^{2}$, 문 $^{\text {철 }}{ }^{1}$ \\ ${ }^{1}$ 세명대학교임상병리학과, ${ }^{2}$ 삼성서울병원 진단검사의학과
}

\begin{abstract}
Dimorphic fungi are characterized by the production of mycelia in the environment or when incubated at lower temperatures $\left(25 \sim 30^{\circ} \mathrm{C}\right)$ on media. The conversion to yeast occurs when invading a human body or when incubated at elevated temperatures $\left(35 \sim 37^{\circ} \mathrm{C}\right)$. Dimorphic fungi cause systemic infection and occur only in endemic regions; they can cause deep mycosis, which invades tissues and organs. Imported thermally dimorphic fungal pathogen has five genera, such as Coccidioides immitis, Histoplasma capsulatum, Blastomyces dermatitidis, Talaromyces (Penicillium) marneffei, and Paracoccidioides brasiliensis. Thus far, 30 cases of dimorphic fungi have been reported in Korea, including C. immitis in 18, H. capsulatumin 5, B. dermatitidis in 3, and T. marneffei in 4 cases. Three 3 cases of $C$. immitis, 2 cases of $H$. capsulatum, 1 case of $B$. dermatitidis, and 1 case of Talaromyces (Penicillium) marneffei were reported in Korea, even though no experience of an epidemic was present. None the dimorphic fungi except for Sporothrix schenkii (Dimorphic fungi) occur in Korea but are caused by endemic fungi that can be found only in specific regions and limited areas of foreign countries. Considering the trends of migratory locals and the increasing number of immigrants living in and returning home, the incidence of imported infections is expected to increase.
\end{abstract}

Key words: Blastomyces dermatitidis, Coccidioides immitis, Dimorphi fungus, Histoplasma capsulatum, Talaromyces (Penicillium) marneffei

This is an Open Access article distributed under the terms of the Creative Commons Attribution Non-Commercial License (http://creativecommons.org/licenses/by-nc/4.0) which permits unrestricted non-commercial use, distribution, and reproduction in any medium, provided the original work is properly cited.

Copyright ( 2018 The Korean Society for Clinical Laboratory Science. All rights reserved.
Corresponding author: Jang Ho Lee Department of Clinical Laboratory Science, Semyung University, 65 Semyung-ro, Jecheon 27136, Korea

Tel: 82-43-649-1620

Fax: 82-43-649-7361

E-mail: jh56lee@semyung.ac.kr

Received: January 31, 2018

Revised: February 2, 2018

Accepted: February 4, 2018

\section{서 론}

두 형태 진균(dimorphic fungi)은 자연환경이나 곰팡이 배 지를 이용하여 실온 $\left(25 \sim 30^{\circ} \mathrm{C}\right)$ 에 배양 할 때에는 균사체의 형 태이나, 조직 내에서나 배지에 접종하여 $35 \sim 37^{\circ} \mathrm{C}$ 에 배양하면 효모균 형태로 나타나는 특징을 가지고 있다. 이들 균종은 모두 병독성이 있으며 지리적으로 발생 빈도가 다르며 조직과 기관 을 침범하는 전신 감염을 일으킬 수 있다[1,2].
사람에게 감염되는 두 형태 진균은 지금까지 Blastomyces dermatitidis, Sporothrix schenkii, Talaromyces(Penicillium) marneffei, Histoplasma capsulatum, 그리고 Paracoccidioides brasiliensis 다섯 균종으로 알려져 있다. 두 형태 진균에 포함되 어 있는 Coccidioides immitis는 지리적으로 한정된 지역에 토 착화 되어 있고, 강한 병독성을 가진 심부 진균증을 일으키는 원 인 진균으로 숙주에 들어온 포자가 체내에서 소구체(spherule) 라는 다핵구조의 구형으로 전환되어 효모 형태를 하고 있지만, 
검체를 배지에 접종하여 $35 \sim 37^{\circ} \mathrm{C}$ 에서 배양을 해도 효모균으 로 자라지 않는다[1,3].

S. schenkii를 제외한 모든 두 형태 진균은 외국의 특정 국가 와 한정된 지역에서만 발생하는 풍토병 원인의 토착 진균이지 만, 유행 지역의 여행 경험이나 호발 지역의 이민 거주자들의 귀 국과 국내로 유입되는 외국인의 증가 추세를 고려하면 해외 유 입되는 두 형태 진균에 의한 감염증(imported case)의 발생은 점점 증가할 것으로 사료된다. 저자들은 진균 검사실에서 경험 하였던 두 형태 진균인 B. dermatitidis (분아균증)와 $T$. marneffei (페니실릴균증)의 분리 사례와 국내 문헌에 보고된 해외 유입 두 형태 진균의 사례들을 고찰하여 보고하고자 한다.

\section{재료 및 방법}

\section{1. 연구대상}

국내에서 보고된 두 형태 진균인 Coccidioides immitis, Blastomyces dermatitidis, Histoplasma capsulatum 그리고 Talaromyces (Penicillium) marneffei의 사례들의 문헌을 고 찰하고, 저자들이 경험한 Blastomyces dermatitidis (분아균 증)와 Talaromyces (Penicillium) marneffei의 사례를 형태학 적 특성과 분자유전학적 동정 결과를 기술하고자 한다.

\section{2. 연구방법}

\section{1) 두 형태 진균의 배양과 동정}

두 형태 진균의 배양은 진료과에서 검체를 채취하여 검사실 로 의뢰하면, Sabouraud dextrose agar (SDA)에 접종하여 25 $30^{\circ} \mathrm{C}$ 에서 3 주간 배양을 하면서 배지를 매일 관찰한다. 증식된 사상균의 성장속도, 색깔, 형태 등을 관찰하여 성숙된 진균으로 자랐다고 판단되면, 성숙된 사상균의 가장자리를 스카치테이 프의 접착 면에 묻힌 후 도말슬라이드에 붙여 lactopheol cotton blue (LPCB)로 염색한다. 광학현미경으로 도말슬라이드 를 관찰하여 균사와 분생자의 형태를 관찰하여 두 형태 진균이 의 심되면, 집락과 보관된 검체를 brain heart infusion (BHI) agar에 다시 접종하여 $35 \sim 37^{\circ} \mathrm{C}$ 에 배양한 후 효모 형태(yeast phase)로 자란 집락을 관찰하였다.

\section{2) 염기서열분석}

형태학적 관찰에서 두 형태 진균의 의심되면 정확한 균종의 확인과 종 수준까지의 동정을 위하여 염기서열분석을 시행하 였다. 염기서열분석을 위한 DNA 분리는 검체 배양에서 자란 집락을 MagNA pure LC total nucleic acid isolation kit로 처
리하여, 자동핵산 추출기 MagNA pure LC 1.0 (Roche Diagnostics Inc., Gemany)를 사용하여 DNA를 추출하였고, PCR 은 thermal cycler model 9700 (Applied Biosystems Inc., $\mathrm{CA}, \mathrm{USA}$ )를 사용하였다. 증폭된 산물의 염기서열분석은 BigDye terminator cycle sequencing ready reaction kit (Applied Biosystems Inc.)와 API Prism 3100 genetic analyzer (Applied Biosystems Inc.)를 사용하였다. 증폭을 위 한 표적부위로는 진균의 염기서열 분석을 통한 동정에 가장 널 리 이용되는 rRNA operon 내의 internal transcribed spacer (ITS) 부위와 $28 \mathrm{~S} \mathrm{rRNA}$ 소단위 일부인 약 $600 \mathrm{bp}$ 크기의 $\mathrm{D} 1 / \mathrm{D} 2$ 를 선택하였다. 증폭된 염기서열은 BLAST (basic local alignment search tool) 알고리즘을 사용하여 GenBank (https://www.ncbi.nlm.nih.gov/genbank/)와 CBS 데이터 베이스(http://www.westerdijkinstitute.nl/collections/)와 비교하여 ITS와 D1/D2 유전자의 염기서열을 종합하여 최종 동정하였다[4].

\section{3) 문헌고찰}

국내에서 발표된 논문을 고찰하기 위하여 KoreaMed (https://www.koreamed.org/)를 통해서 그동안에 발표된 논 문을 검색하였다.

\section{결 과}

\section{1. 두 형태 진균의 경험}

저자들이 경험한 해외에서 유입되어 한국에서 발생한 두 형 태 진균의 분리 사례는 Blastomyces dermatitidis 1 예와 Talaromyces (Penicillium) marneffei 2예 이다. 이들 균주는 진균배양으로 분리하고 배양 온도를 달리하여 효모형과 사상형 을 형태학적 특징으로 동정하고, DNA 염기서열분석으로 최종 확인하였다.

\section{1) Blastomyces dermatitidis}

미국 Tennessee주에 2년 동안 거주하였던 45세 남자가 4개 월 동안 기침과 객담을 증상으로 두 곳의 종합병원에서 도말, 배 양, 그리고 PCR 결핵검사에서 음성의 결과를 보였으나, r/o pulmonary TB로 치료를 받았던 경력을 가지고, 서울소재 대형 종합병원으로 이송되어 일반세균검사와 결핵관련 검사 등 감염 관련 검사에서 모두 음성을 보였으나, 기관지흡입액의 진균배 양검사에서 1 주일 후 백색의 솜털모양의 사상균 집락이 자랐다. 실온에 7일간 더 배양한 후, 스카치테이프를 이용한 도말슬라이 
드를 만들어 lactophenol cotton blue (LPCB)로 염색하여 현 미경으로 관찰한 결과 r/o Emmonsia species로 동정하였다.

처음 경험하는 균주로 정확한 동정을 위하여 $28 \mathrm{~S} \mathrm{rRNA}$ 소단 위의 일부인 D1/D2와 $18 \mathrm{~S}$ ribosomal RNA와 $5.8 \mathrm{~S} \mathrm{rRNA}$ 의 사 이에 존재하는 internal transcribed spacers (ITS) 범위의 유전 자 염기서열 분석을 시행하였다. CLSI Guideline MM18-A에 서 제시하는 방법에 따라 NCBI BLAST를 이용하여 분석한 시험 균주의 $591 \mathrm{bp}$ 에 대한 D1/D2 partial rDNA 유전자의 염기서 열은 등록번호 EF592162.1의 균주 Ajellomyces dermatitidis와 $100 \%$ (591/591) 일치하는 상동성을 보였다. 시험균주의 ITS complete rDNA $620 \mathrm{bp}$ 염기서열 분석 결과는 등록번호 U18364.1의 A. dermatitidis 균주의 염기서열이 99.8\% (619/ 620) 일치하였다. A. dermatitidis는 B. dermatitidis의 유성생 식기 명칭이다[5].

염기서열분석으로 진단한 두 형태 진균인 B. dermatitidis의 효모형태를 확인하기 위하여 실온에서 배양된 균주와 냉장보관 되어있던 검체를 $\mathrm{BHI}$ 에 접종하여 $37^{\circ} \mathrm{C}$ 에서 배양하였다. 배양 1 주일 후 하얀색의 작은 집락이 관찰되었고, 집락을 도말하고 LPCB로 염색하여 효모 형태를 확인하였다(Figure 1).

\section{2) Talaromyces (Penicillium) marneffei}

첫 번째 사례는 이전에 저자들이 보고하였던 사례[6]를 요약 하면, 중국에서 사체 간이식을 받고 서울의 대형종합병원에서
투약을 받으며 경과를 관찰하던 중 기관지 폐렴 의심소견으로 입원하여 경기관지흡입액, 소변, 그리고 혈액배양검사에서 진 균이 배양되었다. 배양초기 집락은 하얀색의 솜털 집락을 보이 다 노란색을 띄었으며 배양 5 일이 지나면서 점차 주황색 집락으 로 변하였고, 뒷면은 적포도주 색으로 변하면서 집락 주변으로 빨강게 퍼져나갔다. 스카치테이프로 집락의 가장자리를 취하 여 도말슬라이드를 만들어 LPCB로 염색하여 현미경으로 관찰 한 결과 분생자병에 난 경자(phialide)들에 사슬 모양의 분생자 들이 관찰되어 Penicillium species로 동정하였다.

집락의 색과 형태가 흔히 분리되는 푸른색의 방선형 주름져 보이는 Penicillium species와는 전혀 다르고, 처음 경험하는 사례로 정확한 종 동정을 하기 위하여 $\mathrm{DNA}$ 염기서열 분석을 시 행하였다.

염기서열 분석은 소변검체에서 배양된 집락에서 $\mathrm{DNA}$ 를 분 리하여 GeneAmp PCR System 9700을 사용하여 증폭시켰고, 증폭된 DNA 절편을 ITS와 D1/D2를 표적부위로 염기서열을 분석하여 각각 $548 \mathrm{bp}, 489 \mathrm{bp}$ 의 염기서열을 얻었다. 시험균주 의 D1-D2 구역 염기서열을 NCBI Blast search를 통해 분석 한 결과 Talaromyces marneffei (GenBank 등록번호 $\mathrm{AB} 362755.1)$ 과 $100 \%$ (594/594) 상동성을 보였으며, ITS의 염기서열에서도 T. marneffei (등록번호 FJ009566.1)과 100\% (481/481) 일치하는 상동성을 보여 T. marneffei로 확인하였 다[6].
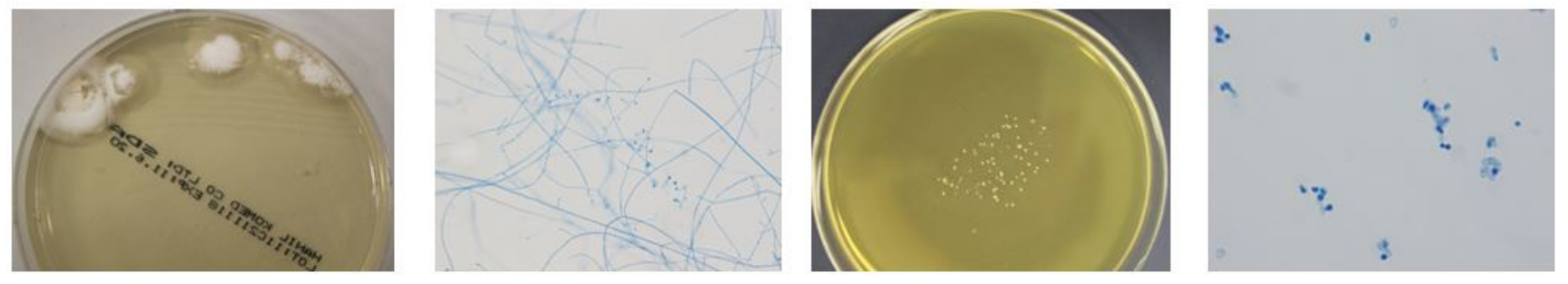

Figure 1. Colonial morphology of Blastomyces dermatidis on SDA $\left(25^{\circ} \mathrm{C} 14\right.$ days, left), LPCB stain of colony ( $\times 400$, left middle), yeast phase colony on $\mathrm{BHI}\left(35^{\circ} \mathrm{C} 7\right.$ days, right middle), and LPCB stain of yeast phase colony (right).
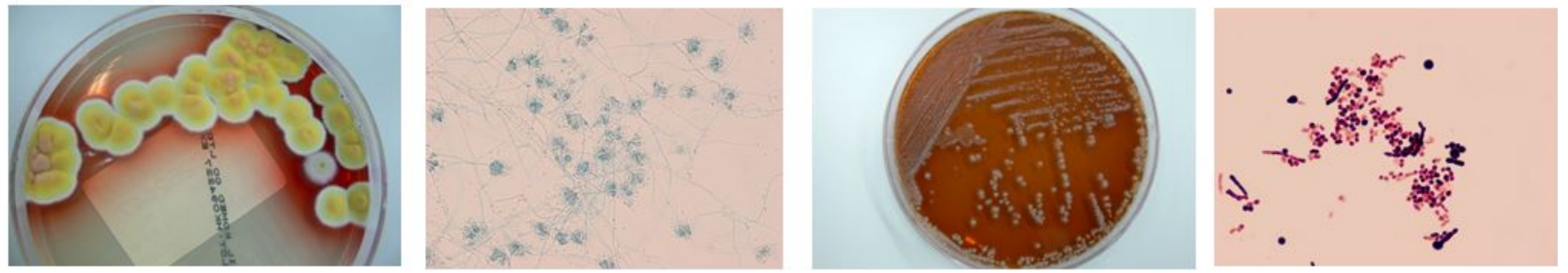

Figure 2. Colonial morphology of Talaromyces marneffei(formerly Penicillium merneffel) on SDA $\left(25^{\circ} \mathrm{C}, 8\right.$ days, left), LPCB stain of colony ( $\times 400$, left middle), yeast phase colony on $\mathrm{BHI}\left(35^{\circ} \mathrm{C}, 12\right.$ days, right middle), and Gram stain of yeast phase colony (right).

*Abbreviations: SDA, sabouraud dextrose agar; BHI, brain heart infusion agar; LPCB, lactophenol cotton blus. 
T. marneffei의 효모형태를 확인하기 위하여 균주와 보관검 체를 $\mathrm{BHI}$ 에 접종하여 $37^{\circ} \mathrm{C}$ 에서 배양하여 1 주일 후 배지 주변으 로 붉은색의 색소형성을 하는 황백색의 효모 형 집락을 관찰하 였고, 집락을 도말하고 LPCB로 염색하여 효모 형태를 확인하였 다(Figure 2).

두 번째 사례는 25세 남자 환자가 콧물과 기침을 주소로 서울 소재 대형병원에 내원하였다. 환자는 4년 전 AIDS 진단을 받아 항 네트로 바이러스 치료를 받는 중 이었다. 환자는 2 달 전 중국 에 다녀온 여행력이 있었으며 오한, 기침, 콧물 등의 증상의 악 화로 내원하였다. 내원 당시 혈액배양검사를 시행하였고, 배양 36 시간째 환자의 혈액배양병에서 양성 시그널이 확인되었다. 혈액 배양 검체로 시행한 그람염색에서 균사가 관찰되었고, 진 균배양 검사 결과 노란색의 솜털 집락과 집락의 가장자리와 뒷 면의 적포도주 색을 띠는 전형적인 T. marneffeis와 일치하는 양 상을 보였다. 이후 $\mathrm{LPCB}$ 도말을 만들어 현미경 관찰에서 Penicillium species와 합당한 소견을 보여 T. marneffei로 최 종 보고하였다. 첫 번째 사례와 형태와 색깔 등 배양소견이 같아 분자생물학적 동정은 시행하지 않았다.

\section{2. 문헌으로 보고된 국내에서 발생한 두 형태 진균 사례}

한국에서 보고된 해외 유입 두 형태 진균은 Coccidioides immitis 18예, Histoplasma capsulatum 5예, Blastomyces dermatitidis3예, 그리고 Talaromyces (Penicillium) marneffei 3 예가 국내 저널을 통해서 보고된 것으로 확인하였다.

C. immitis에 의한 18 예 가운데 8예는 배양검사로 균주를 확 인하였고, 10 예는 영상의학적 소견과 병리학적 소견으로 진단 한 사례이었다. 코시데오디스 진균의 유행지역을 경험한 사례 가 15 건이고 풍토지역을 여행한 경험이 없는 사례가 3 건이었다 (Table 1).

H. capsulatum 은 5예 가운데 배양검사로 균주를 확인한 사 례는 1예 뿐이었으며 4예는 병리학적 소견으로 histoplasmosis 를 진단한 사례였다. 유행지역을 경험한 사례는 2건이고 3예는 퐁토직역의 경험이 없는 사례이었으며, 1 예에서 배양검사로 균 주를 확인하여 진단하였다(Table 2).

B. dermatitidis3예는 폐감염 2예와 족부 골 감염 1예로 모두 균주를 배양검사로 확인한 사례였으며, 이 가운데 1예는 토착지

Table 1. Review of previous published cases with Coccidioides immitis in Korea

\begin{tabular}{|c|c|c|c|c|c|}
\hline Case No & Specimens & Culture isolated & Final diagnosis & Relation to endemic area & Published year \\
\hline 1 & Lung tissue & + & Culture \& Pathological & California & 2015 \\
\hline 2 & Sputum \& Lung tissue & - & Pathological & Arizona & 2012 \\
\hline 3 & CSF & + & Culture \& Serological & Arizona, LA, Florida & 2012 \\
\hline 4 & Lung tissue & + & Culture \& Pathological & California & 2009 \\
\hline 5 & Lung tissue & - & Pathological & Arizona & 2009 \\
\hline 6 & Skin tissue & - & $"$ & None & 2008 \\
\hline 7 & Pelvic bone \& abscess & + & Culture \& Pathological & California & 2006 \\
\hline 8 & Lung \& Skin Tissue & - & Pathological & New Mexico & 2006 \\
\hline 9 & Skin tissue & + & Culture & New Mexico & 2005 \\
\hline 10 & Lung tissue & - & Serological \& Pathological & Arizona & 2005 \\
\hline 11 & Sputum \& Skin Tissue & - & Pathological & None & 2005 \\
\hline 12 & Skin Tissue & + & Culture \& Pathological & North Mexico & 2004 \\
\hline 13 & Lung tissue & - & Pathological & Arizona & 2001 \\
\hline 14 & Lung tissue & - & $" \prime$ & Arizona & 1999 \\
\hline 15 & Lung tissue & - & $"$ & Arizona & 1999 \\
\hline 16 & Lung tissue & - & " & Arizona & 1999 \\
\hline 17 & Autopsy Lung tissue & + & Culture & California & 1996 \\
\hline 18 & Skin tissue & + & " & None & 1976 \\
\hline
\end{tabular}

Table 2. Review of previous published cases with Histoplasma capsulatum in Korea

\begin{tabular}{cccccc}
\hline Case No & Specimens & Culture isolated & Final diagnosis & Relation to endemic area & Published year \\
\hline 1 & Lung tissue & + & Culture \& Pathological & None & 2018 \\
2 & Lung tissue & - & Pathological test & Honduras & 2016 \\
3 & Lung tissue & - & $"$ & None & 2012 \\
4 & Bone marrow & - & Guatemala & 2007 \\
5 & Blood smear & - & Newborn & 1991 \\
\hline
\end{tabular}


Table 3. Review of previous published cases with Blastomyces dermatitidis in Korea

\begin{tabular}{cccccc}
\hline Case No & Specimens & Culture isolated & Final diagnosis & Relation to endemic area & Published year \\
\hline 1 & Lung tissue & + & Culture \& sequencing Pathological & Tennessee & 2012 \\
2 & Tissue & + & Culture \& Pathological & None & 2005 \\
3 & Lung tissue & + & Pathological & Arizona & 2005 \\
\hline
\end{tabular}

Table 4. Review of previous published cases with Talaromyces (Penicillium) marneffei in Korea

\begin{tabular}{|c|c|c|c|c|c|}
\hline Case No & Specimens & Culture isolated & Final diagnosis & Relation to endemic area & Published year \\
\hline 1 & Skin tissue & + & Culture & Laos & 2012 \\
\hline 2 & Blood & + & Culture & China & 2012 \\
\hline 3 & Blood, Urine, Sputum & + & Culture \& Sequencing & China & 2010 \\
\hline 4 & Lung tissue & + & Culture \& Sequencing & None & 2002 \\
\hline
\end{tabular}

역의 방문 경험이 없는 사례였다(Table 3).

T. marneffei 4 예도 모두 배양검사로 균주를 확인한 사례였 으며 저자가 배양하여 진단한 2예는 중국에서의 사체 간이식하 고 돌아와 국내에서 치료 중에 발생 사례와 중국 남부지방의 여 행력이 있는 AIDS 감염자에서 발생한 사례로, 1 예는 AIDS 감염 력과 토착지역의 방문 경험이 없는 사례였다(Table 4).

\section{고 찰}

배양 온도에 따라 효모균과 사상균 두 가지 양상을 다 보이는 진균을 두 형태 또는 이형태(dimorphic) 진균으로 칭하는데, 일반적으로는 $25 \sim 30^{\circ} \mathrm{C}$ 에서는 사상균으로 자라고 $35 \sim 37^{\circ} \mathrm{C}$ 에서는 효모균으로 성장한다. 두형태 진균은 지리적으로 발생 빈도가 다르며 조직과 기관을 침범하는 전신 감염을 일으킬 수 있다[1,2].

인체에 감염을 일으키는 두 형태 진균은 S. schenkii, T. marneffei, B. dermatitidis, H. capsulatum, P. brasiliensis 그 리고 Coccidioides immitis를 포함하면 여섯 균종으로 알려져 있다. 이들 균종들 중에 S. schenkil만이 유일하게 국내뿐만 아 니라 범세계적으로 분리되는 진균으로 국내에서도 피부변병 등 에서 분리된 많은 사례 등이 발표되었다[7]. S. schenkii를 제외 한 두 형태 진균들은 해외에서 유입되는 균종들로 미국의 일부 지역 등 특정 지역에서만 분리되는 풍토병의 원인 진균이다.

Coccidioides immitis는 미국 남서부, 멕시코, 그리고 중남 미 일부 지역에서 발생하는 풍토성 곰팡이 감염의 원인 진균이 다. 감염의 대부분은 미국 남부 애리조나, 캘리포니아의 중심부 또는 뉴멕시코 남부 및 텍사스 서쪽의 지역에서 발생하지만, 유 행성 지역을 방문한 여행자 또는 이전에 감염되었던 환자나 보 균자가 면역 억제 상태가 지속되면 다시 임상 질환을 일으킬 수
있어 유행 지역 외의 지역에서도 의료 관리를 할 필요가 있다[8].

1990년대까지 Coccidioides속은 Coccidioides immitis 오 직 하나의 종(species)만을 가지고 있다고 생각했다. 이 후 분자 계통 발생학적 방법으로 캘리포니아, 애리조나, 텍사스, 멕시 코, 남아메리카 등 지리적 위치가 다른 곳에서 유래된 균주간에 명확한 차이가 있음을 밝혀냈다. 그 결과 캘리포니아로부터 유 래된 분리 균주는 C. immitis의 종명을 유지했고, 애리조나 등 캘리포니아 이외의 지역에서 유래되어 분리된 균주를 $C$. posadasii 라고 명명하였다. 그러나 C. immitis와 C. posadasii 를 표현형 적으로 구별하는 것은 어렵고, 두 종이 거의 동일한 임 상적 표현과 항진균제 감수성 양상을 갖고 있기 때문에 두 종을 일상적으로 구별하는 것은 임상적으로 불필요하다고 제안하고 있다[9]. 국내에서 보고된 문헌들에서는 아직까지 C. posadasii 를 보고한 사례는 없었다.

Coccidioides는 토양과 같은 환경에서는 격막이 있는 균사 (septate hyphae)와 두꺼운 벽을 가진 분절포자(arthroconidia, $2 \times 4 \mu \mathrm{m})$ 의 생성을 특징으로 한다. 토양의 분절포자는 바람에 의해 공기 중에 쉽게 방출되어 폐에 흡입되거나 피부 등에 감염 되어 체내에서 무성생식을 하여 내생포자를 함유하는 구상체 (spherule) 형성한다. 800에서 1,000개에 이르는 내생포자는 다양한 조직에 감염을 일으킨다[8,9].

C. immitis에 의한 국내감염은 1978년 척추경막 내 농양의 보고 사례가 처음이었으며[10], 이 후 현재까지 총 18 예의 증례 가 보고되었다. 이들 중에 배양검사에서 균주를 분리하여 확인 한 사례는 8예 이었고, 조직검사와 영상의학 소견으로 진단한 사례가 10 예가 보고되었다. 감염부위 별로는 폐 감염이 11예로 가장 많았고, 피부 병변이 4예, 골수염 1예, 농양 1 예, 그리고 뇌 척수액 1예가 보고되었다[10-23].

유행지역의 여행이나 거주 경험자는 15 명으로 아리조나 7명 
으로 가장 많았고, 캘리포니아 4 명, 뉴멕시코 2 명, 북부멕시코 1 명, 그리고 아리조나, 로스앤젤레스, 플로리다 중복 지역 여행이 1 예이었고, 전혀 유행지역의 여행 검험이 없는데도 감염된 사례 가 3명이었다[10-23]. 아리조나는 인구 10만 명당 90명이 발생 할 정도로 미국에서도 호발지역이다[9].

Coccidioides spp.의 검사실 검사는 직접 현미경검사, 배양 검사, 혈청학적검사, 그리고 병리학적 검사로 진단을 한다. 검체 의 현미경검사를 위한 도말 염색은 Grocott methenamine silver (GMS)와 calcofluor white (CFW)가 유용하고, 병리학 적 검사로는 hematoxylin-eosin (H\&E) 염색과 periodic acid Schiff (PAS) 염색이 이용된다. 배양검사에는 SDA 등 진균배지 뿐만 아니라 혈액우무배지와 초코릿우무배지에서도 4-5일 이 면 집락을 관찰 할 수 있다. Coccidioidesspp.의 동정은 집락의 도말에서 분절포자의 관찰이 중요하며, 반드시 생물학적 안전 수 준 2 또는 3 을 유지하는 시설을 갖춘 곳에서 시행하여야 한다[9].

Histoplasmosis의 원인균인 Histoplasma capsulatum은 북미의 미시시피와 오하이오 강의 계곡에 토착화되어 있는 병 독성이 매우 강한 이형진균으로 알려져 있지만 중남미, 아프리 카 및 아시아의 특정 지역에서 발병하며 유럽에서도 사례가 보 고되고 있다. H. capsulatum은 축축한 토양, 특히 부패하는 새 등의 배설물을 좋아한다. 박쥐는 위장관에, 새는 깃털에 이 곰팡 이를 가지고 있지만, 새는 높은 체온 $\left(40^{\circ} \mathrm{C}\right)$ 으로 인해 영향을 받 지 않는다. 인체의 감염은 이러한 히스토플라스마의 독특한 성 장 요구 조건을 갖춘 오염 국소지역(microfoci)에서 접촉과 바 람에 의해 날린 H. capsulatum의 포자에 노출된 것과 관련이 있다. 일반적으로 감염되어도 증상이 없지만, 육아종성염증으 로 인해 폐결핵과 유사한 폐 질환이 발생하고, 면역 저하 환자에 서는 높은 이환율과 사망률을 초래할 수 있다[24-26].

국내에서 Histoplasmosis는 1991년 신생아의 말초혈액도 말에서 진단하여 보고된[27] 사례를 포함하여 5예가 보고되었 다. 5예 가운데 배양검사에서 균주를 확인 한 사례는 최근에 폐 조직의 배양검사에서 확인한 1예가 유일하고, 나머지 4예는 병 리학적 소견과 혈청학적 검사 소견으로 진단한 사례이다. 유행 지역의 여행이나 거주 경험은 2예로 온두라스와 과테말라 지역 이었다[27-31].

Histoplasma capsulatum의 일차 감염은 증상이 없거나 가 벼운 독감 같은 증상으로 환자가 무시하는 경향이 있다. 전형적 인잠복기는 7 21일이며 고열, 두통, 마른기침, 흥통이주요 증 상이다. 전통적인 진단 방법으로 병리학적 검사는 최종 진단의 한계와 배양검사는 $25 \%$ 미만의 양성률을 보이고 있어 혈청학 적 검사를 많이 이용한다. 라텍스 응집검사는 보체결합반응검
사나 면역확산법 보다 우수하지만 위양성을 배제할 수 없으며, B. dermatitis 감염과 구별 할 수 없다. 효모 세포 추출물을 사용 하는 ELISA 방법은 급성 폐 감염증에서 anti-human IgG를 사 용하여 $91 \%$ 의 특이성과 $86 \%$ 의 민감성을 보인 반면, antihuman IgM에서는 66\%의 민감성과 $100 \%$ 의 특이성을 보인다 고 보고하였다[24,25].

H. capsulatum는 전 세계적으로 대륙에 존재하는 풍토병이 다. 유럽의 이태리, 북미, 중남미, 서아프리카의 콩고와 짐바브 웨, 남아프리카 공화국, 동남아시아의 인도, 중국, 말레이시아, 대만, 그리고 호주에서도 사례가 보고되었다. 전 세계 인구의 절 반 이상이 H. capsulatum의 고유 지역에 살고 있다[26]. 최근 국내에 보고된 균주 배양 사례에서 보듯이 유행지역의 경험이 없음에도 감염환자가 발생하였다[28]. 이는 우리나라도 히스토 플라스마에 대한 의료 관리에 관심을 가져야 한다는 것을 시사 한다.

Blastomyces dermatitidis는 분아균증(blastomycosis)을 일으키는 두 형태 진균으로, 유성생식(sexual state) 형은 Ajellomyces dermatitidis라 명명한다. B. dermatitidis는 주로 미국의 중서부와 동남부 지역의 미시시피 또는 오하이오 주의 강 또는 호수주변에 분포하며 풍토병인 분아균증을 일으킨다. 이 진균에 의한 감염은 대부분 폐에 감염되어 피부, 뼈, 그리고 몸 전체로 이행되어 만성진균 감염을 일으킨다[32].

국내에서 보고된 분아균증 3예는 모두 폐조직과 족부 조직에 서 B. dermatitidis 균주를 확인한 사례이며, 족부 골을 침범한 1 예는 유행지역의 경험이 없었던 사례였다[5,33,34]. 이 가운 데 1 예는 저자가 경험했던 사례로 이미 전등에 의해 폐결핵으로 오인된 폐분아균증이라는 증례[33]와 Park 등에 의해 검사실의 경험[5]을 레터 형식으로 보고되었다.

저자들의 사례를 요약하면, 45 세 남자 환자가 미국의 테네 시에서 2 년을 거주했고, 흥농을 주소로 서울의 대형병원에 입원 하여 $\mathrm{BAL}$ 검체로 진균 배양검사가 의뢰되었다. 검체를 $\mathrm{SDA}$ 에 접종한 후 실온에서 배양한지 7일 만에 백색의 솜털모양의 집락 이 관찰되었다.

호흡기 검체에서 백색의 집락은 오염균이 대부분이어서 의 미를 두지 않고 동정을 하지 않는 것이 통상적이었으나, BAL 검 체에서 자란 집락이 기존의 백색 집락과는 다른 양상을 보여 스 카치테이프로 집락을 취하여 LPCB 도말을 만들어 현미경 관찰 하였으나 동정의 근거가 되는 분생자가 관찰되지 않아 파라필 름으로 봉입하여 1 주일을 더 실온에 배양하여, 집락의 가운데부 터 연한 노란 빛을 보이고, 뒷면은 주황색으로 선명하게 보이는 집락으로 자랐다. 
집락을 스카치테이프에 묻혀 LPCB 도말슬라이드를 만들 어 현미경으로 관찰하여, 격막이 있는 가늘고 긴 균사에서 직각 으로 분지된 짧은 분생자병 끝에 달려있는 아주 작은 구형의 분 생자를 확인하여, 형태학적으로 r/o Emmonsia species로 보 고하였다.

처음 분리한 균주로 정확한 동정을 위하여 $18 \mathrm{~S}$ ribosomal $\mathrm{RNA}$ (rRNA)와 5.8S rRNA의 사이에 존재하는 ITS와 $28 \mathrm{~S}$ $\mathrm{rRNA}$ 소단위의 일부인 D1/D2 유전자 염기서열 분석을 하여 D. dermatitidis와 가장 높은 상동성을 보여, 집락을 $\mathrm{BHI}$ 배지 접종하여 $35^{\circ} \mathrm{C}$ 배양기에서 10 일간 배양하여 하양게 자라는 효 모형을 확인하여 최종적으로 D. dermatitidis로 동정하였다 [5].

Talaromyces (Penicillium) marneffei는 동남아시아에서 전신성 진균증을 일으키는 중요한 병원성 두 형태 진균이다. $T$. marneffei의 감염은 열대 지방, 특히 태국, 베트남, 인도 북동부, 중국 남부, 홍콩, 대만, 라오스, 말레이시아, 미얀마, 캄보디아 및 라오스에서 빈번하게 발병한다. T. marneffei 유행지역에서 는 T. marneffei에 의한 감염이 결핵과 크립토 코커스증과 함께 오랫동안 $\mathrm{AIDS}$ 를 정의하는 중요한 감염 중 하나로 간주되어 왔 으나, 최근 몇 년 동안 유행지역에서 AIDS 감염병의 통제와 HIV 감염 치료가 개선되면서 T. marneffei 감염병 환자가 줄어들고 비HIV 감염 환자 증가하고 있다고 보고하고 있다[35].

국내에서 분리된 T. marneffei 4 예 가운데 2예가 AIDS 환자 에게서 분리되었다[36]. 두 사례 모두 중국과 라오스를 방문한 경험이 있는 환자이다. 1 예는 중국에서 사체 간 이식을 받고 돌 아와 이식 후 치료와 경과 관찰을 하던 중에 발생한 사례로[6], 풍토병 지역과 연관 된 것으로 사료된다. 그러나 1 예는 풍토병 유 행 지역과 관계없이 발병 지역에 노출되지 않은 비 AIDS 환자가 P. marneffei의 풍토병 유행 지역 아닌 한국에서 발생했다[37]. 저자들의 경험과 문헌고찰을 통하여 두 형태 진균의 국내 감 염 사례는 해외의 풍토병 유행지역의 방문 경험이 있는 면역저 하 환자들뿐만 아니라, 해외의 여행력이 없는 면역 저하 환자에 서도 발생한다는 것은 보고 있다. 향후 병독성 두 형태 진균의 감 염사례는 주의 깊게 추적관찰이 필요할 것으로 사료된다.

\section{요 약}

두 형태 진균은 자연환경이나 배지에 접종하여 실온에(25 $30^{\circ} \mathrm{C}$ )에서 배양하면 균사체를 형성하는 특성을 가지고 있으며, 체온이나 높은 온도 $\left(35 \sim 37^{\circ} \mathrm{C}\right)$ 에서 배양을 하면 효모형태를 나 타나는 특성이 있다. 풍토병 지역에서만 발생하는 이들은 전신
감염을 일으키며, 조직이나 기관에 침입하여 심부 진균 증을 일 으키는 원인 진균이다.

사람에 감염되는 두 형태 진균은 지금까지 Blastomyces dermatitidis, Coccidioides immitis, Sporothrix schenkii, Talaromyces (Penicillium) marneffei, Histoplasma capsulatum, 그리고, Paracoccidioides brasiliensis 여섯 균 종으로 알려져 있다. 지금까지 해외에서 유입되어 국내에 보고 된 두 형태 진균은 Coccidioides immitis 가 18예, Histoplasma capsulatum이 5예, Blastomyces dermatitidis가 3예, 그리고 Talaromyces (Penicillium) marneffei 가 4예로 모두 30예의 두 형태 진균이 보고되었다. 유행지역의 방문경험이 없음에도 국내에 발생된 경우는 C. immitis가 3예, H. capsulatum이 2 예, B. dermatitidis가 1예, 그리고 Talaromyces (Penicillium) marneffei 가 1 예로 있다.

Sporothrix schenkii를 제외한 모든 두 형태 진균이 국내에 서는 발생하지 않고 외국의 특정 국가와 한정된 지역에서만 발 생하는 풍토병 원인의 토착 진균이지만, 유행 지역의 여행 경험 이나 호발 지역의 이민 거주자들의 귀국과 국내로 유입되는 외 국인의 증가 추세를 고려하면 해외유입 감염증의 발생은 점점 증가할 것으로 사료된다.

Acknowledgements: This paper was supported by Semyung University in 2017.

Funding: None

Conflict of interest: None

\section{REFERENCES}

1. Larone DH, editor. Medically important fungi: A guide to identification. 5th ed. Washington DC: ASM Press; 2011.

2. Lee NY, Heo HJ, et al. Clinical cases in medical mycology. 1st ed. Seoul: anmun education; 2015. p133-172.

3. Akram SM, Koirala J. Coccidioidomycosis: StatPearls Publishing; 2017 Jun-.2017 Oct 9.

4. Lee JH, Koo BK. Study of Aspergillus species from clinical specimen isolate. Korean J Clin Lab Sci. 2016;48(1):15-21.

5. Park KS, Ki CS, Lee NY. Laboratory experience in phenotypic and molecular identification of Blastomyces dermatitidis first isolated in Korea. Korean J Clin Microbiol. 2012;15(3):114-116.

6. Seo JY, Ma YE, Lee JH, Lee ST, Ki CS, Lee NY. A case of disseminated Penicillium marneffei infection in a liver transplant recipient. Korean J Lab Med. 2010;30(4):400-405.

7. Park HS, Yun SJ, Lee JB, Kim SJ, Lee SC, Won YH. Clinical analysis of the 118 cases of sporotrichosis over 42 years in Kwangju and Chonnam (1967-2009). Korean J Med Mycol. 2011; 16(4):172-178. 
8. Galgiani JN, Ampel NM, Blair JE, Catanzaro A, Johnson RH, Stevens DA, et al. Coccidioidomycosis. Clin Infect Dis. 2005; 41(9):1217-23.

9. Saubolle MA, McKellar PP, Sussland D. Epidemiologic, clinical, and diagnostic aspects of coccidioidomycosis. J Clin Microbiol. 2007;45(1):26-30.

10. Lee JW, Kim SI, Kim YJ, Kwon JC, Lim YJ, Park MH, et al. A case of Coccidioidal meningitis. Infect Chemother. 2012;44(2):75-79.

11. Oh JH, Kim HS, Yoon KT, Kang Y, Min C, Koo SM, et al. Acute pulmonary coccidioidomycosis and review of published cases with lung involvement in Korea. Soonchunhyang Med Sci. 2015;21(2):159-163.

12. Lee JM, Bae SH, Lee SN, Park KH, Park CK, Yoon HK, et al. A case of disseminated coccidioidomycosis involving the lymph nodes, the skin, and the brain. Korean J Med. 2012;82(6):734-738.

13. Baek JH, Park EY, Jung YS, Hong JW, Chae Y, Jin SJ, et al. Recurrent coccidioidomycosis manifesting as osteomyelitis in Korea. Infect Chemother. 2009;41(4):253-257.

14. Kim SW, Oh JY, Kim EJ, Park GM. Pulmonary coccidioidomycosis in immunocompetent patient. Tuberc Respir Dis. 2009; 66(3):220-224.

15. Chang S, Shim SH, Kwak JE, Joo M, Kim H, Park HJ, et al. A case report of cutaneous coccidioidomycosis. Korean J Pathol. 2008; 42(4):223-225.

16. Park JC, Kim JH, Ku NS, Lee KH, Choi YK, Lee YH, et al. A case of disseminated coccidioidomycosis with pelvic bone and paravertebral abscess. Infect Chemother. 2006;38(5):296-299.

17. Kim JH, Hur GY, Jung KH, Jung HC, Park DW, Lee SY, et al. Disseminated coccidioidomycosis presenting with miliary nodules. Tuberc Respir Dis. 2006;60(1):97-101.

18. Kim YJ, Cho HM, Kim JH, Kim IH, Shin C, Son SW. Disseminated coccidioidomycosis with cutaneous manifestation. Korean J Dermatol. 2005;43(10):1379-1382.

19. Sinn DH, Kwon YS, Choi SY, Chang WI, Park MK, Han J, et al. A case of pulmonary coccidioidomycosis mimicking lung cancer. Korean J Med. 2005;69(4):419-423.

20. Han SY, Kim CH, Son KP, Kim JK, Byun HW, Kim YS, et al. A case of disseminated coccidioidomycosis involving lung and skin in patient with diabetes mellitus and iatrogenic cushings syndrome. Tuberc Respir Dis. 2005;58(4):399-403.

21. Park DJ, Jang YH, Lee SJ, Na GY, Kim DW, Kim SW. A case of coccidioidomycosis showing cutaneous and pulmonary nodules. Korean J Med Mycol. 2004;9(3):190-195.

22. Jones JM, Koski L, Khan M, Brady S, Sunenshine R, Komatsu KK Coccidioidomycosis: An underreported cause of death-Arizona, 2008-2013. Med Mycol. 2018;56(2):172-179.

23. Shin JS, Lee IS, Shin C, Kim A. Pulmonary coccidioidomycosis diagnosed in an immigrant. Tuberc Respir Dis. 2001;51(5):448452.

24. Wheat LJ, Freifeld AG, Kleiman MB, Baddley JW, McKinsey DS, Loyd JE, et al. Clinical practice guidelines for the management of patients with histoplasmosis: 2007 update by the Infectious Diseases Society of America. Clin Infect Dis. 2007;45(7):807-25.

25. Akram SM, Koirala J. Coccidioidomycosis: StatPearls Publishing; 2017 Jun-.2017 Oct 9

26. Azar MM, Hage CA. Clinical perspectives in the diagnosis and management of histoplasmosis. Clin Chest Med. 2017;38(3): 403-415.

27. Jeon DS, Kim JR, Chun HJ, Hong YA, Kim WT. A case of histoplasmosis diagnosed on peripheral blood smear. Korean J Hematol. 1991;26(2):391-396.

28. Lee YJ, Kang HR, Song JH, Sin S, Lee SM. Pulmonary histoplasmosis identified by video-assisted thoracic surgery (VATS) biopsy: A case report. J Korean Med Sci. 2018;33(2):e15.

29. Choi SJ, Choi HS, Chun JY, Kim CJ, Lee MJ, Kim M, et al. Subacute progressive disseminated histoplasmosis in immunocompetent patient. Korean J Intern Med. 2010;31(5):9991002.

30. Jung EJ, Park DW, Choi JW, Choi WS. Chronic cavitary pulmonary histoplasmosis in a non-HIV and immunocompromised patient without overseas travel history. Yonsei Med J. 2015; 56(3):871-874

31. Jeong HW, Sohn JW, Kim MJ, Choi JW, Kim CH, Choi SH, et al. Disseminated histoplasmosis and tuberculosis in a patient with HIV infection. Yonsei Med J. 2007;48(3):531-534.

32. Saccente M, Woods GL. Clinical and laboratory update on blastomycosis. Clin Microbiol Rev. 2010;23(2):367-381.

33. Jhun BW, Kim DM, Park JH, Yoo HS, Shim H, Kim JG, et al. A case of pulmonary blastomycosis mimicking pulmonary tuberculosis. Tuberc Respir Dis. 2012;72(1):77-81.

34. Cho JH, Suh JS, Kim JH. Systemic blastomycosis with osseous involvement of the foot: A case report. J Korean Foot Ankle Soc. 2005;9(2):216-219.

35. Chan JF, Lau SK, Yuen KY, Woo PC. Talaromyces (Penicillium) marneffei infection in non-HIV-infected patients. Emerg Microbes Infect. 2016;5(3):e19.

36. Jung JY, Jo GH, Kim HS, Park MY, Shin JH, Chin BS, et al. Disseminated penicilliosis in a Korean human immunodeficiency virus infected patient from Laos. J Korean Med Sci. 2012;27(6):697-700.

37. Han SH, Choi HY, Lee SC, Goo YS, Chang KH, Kang SW, et al. A case of Penicillium maneffei CAPD peritonitis. Korean J Nephrol. 2002;21(4):680-685. 